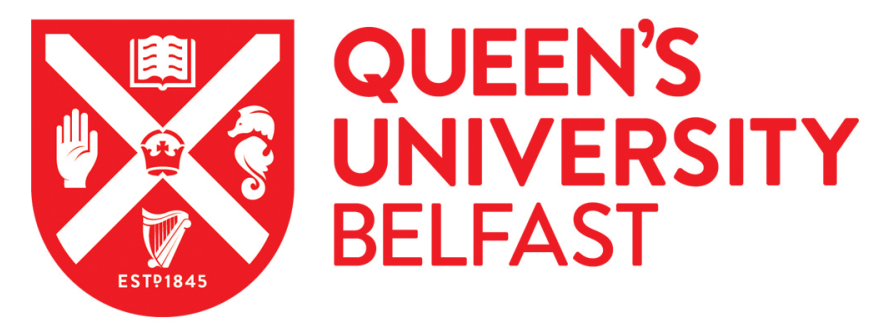

\title{
Rural governance: Participation, Power and Possibilities for Action
}

Swindal, M. G., \& McAreavey, R. (2012). Rural governance: Participation, Power and Possibilities for Action. In M. Shucksmith, D. L. Brown, S. Shortall, J. Vergunst, \& M. E. Warner (Eds.), Rural Transformations and Rural Policies in the US and UK (pp. 269-286). Routledge. https://www.routledge.com/products/9780415890106

Published in:

Rural Transformations and Rural Policies in the US and UK

Document Version:

Peer reviewed version

Queen's University Belfast - Research Portal:

Link to publication record in Queen's University Belfast Research Portal

Publisher rights

(C) 2012 - Routledge

This is an Accepted Manuscript of a book chapter published by Routledge in Rural Transformations and Rural Policies in the US and UK on 27 Feb 2012, available online: https://www.routledge.com/products/9780415890106

\section{General rights}

Copyright for the publications made accessible via the Queen's University Belfast Research Portal is retained by the author(s) and / or other copyright owners and it is a condition of accessing these publications that users recognise and abide by the legal requirements associated with these rights.

Take down policy

The Research Portal is Queen's institutional repository that provides access to Queen's research output. Every effort has been made to ensure that content in the Research Portal does not infringe any person's rights, or applicable UK laws. If you discover content in the Research Portal that you believe breaches copyright or violates any law, please contact openaccess@qub.ac.uk. 


\section{Rural governance: Participation, Power and Possibilities for Action}

\section{Ruth McAreavey \& Megan G Swindal}

March 2010

word count 9019

\section{Introduction: the importance of participation}

Historically the concept of participation has been valued within western societies as they made the transition from agricultural to industrial based economies and the dangers of non-participation were highlighted (Durkheim 1893; Tonnies 1955[1881]; Park 1952; Marx 1959). Politicians and policymakers continue to be attracted for ideological and economic reasons. It is seen to generate social capital through which actors are able to secure benefits by virtue of membership in social networks or other structures (Bourdieu 1986; Putnam 1993; Coleman 1990). Putnam also famously implies that civic participation leads to economic development; this lucrative connection appealing to financially constrained policymakers (Portes 1998).

Participation therefore remains of central importance to modern social structures. The belief is that decentralisation and participation makes for better government as it brings government spatially closer to people and increases the availability and quality of information from citizens to government. And so it enables citizens to more actively participate in structures of governance achieving greater social and economic inclusion (Commins 2004). It also 'adds a different and valuable dimension to local decisionmaking processes' (Stoker 2005:12) in that it gives individuals opportunities but also requires them to accept obligation (Blair 1994). This helps resolve tension between the state, market and community and it provides a 'softer' more people centred approach than is otherwise possible (Adams and Hess 2001:258). Different degrees of participation are evident, for instance local authorities aim to use their powers to enable rather than control (Taylor 2000). Indeed across Europe Callanan (2005) shows how a variety of different participative mechanisms is used by governments to facilitate participatory democracy. At the same time, the 'mythologising' (Hayward et al. 2004: 95) power of participation is 
evident, for instance in the UK the New Labour government views public participation as achieving the following - improving the quality and legitimacy of public bodies decision making; addressing the democratic deficit; and building community capacity and social capital (Barnes et al. 2003).

Using case studies from the USA and the UK, this chapter examines the efficacy of structures of governance. It does this by considering the way in which different actors participate in rural development within different ideological frameworks. The analysis pays particular attention to power relations within the process. The following section reviews agendas of participatory governance before presenting empirical evidence from the USA and the UK. Following public sector reform and ongoing restructuring of rural development policy and programmes, it scrutinises rural development activity within the state of Alabama before examining the European rural development framework that has emerged within Northern Ireland. Our analysis illustrates how processes of governance are interpreted differently across space. However, despite distinct administrative and political understanding of rural development, the research reveals that the opportunities for 'real' community participation, and the spaces that exist for meaningful engagement of 'the community', are limited and indeed threatened by boundaries and elites that curtail possibilities for action.

\section{Agendas of participatory governance}

In recent years the proliferation of local partnerships between public and civil society sectors has indicated a global policy shift from government to governance (OECD 2001). Citizen participation is a central feature of these new arrangements. Arnstein (1969) famously encapsulated the nuances of participation, connecting citizen power to degrees of participation so that to achieve control citizens must have complete power. She points out that in situations where final approval, power and accountability lie with another agency then citizen control cannot be achieved. Bearing in mind that 'government in most states retain control over the key policy levers' (Ayres and Pearce 2008:540), then it must be the case that in processes of governance, citizen control is not the primary objective. Governance embraces the notion of market rationality where states 'stay at 
arms-length from market forces, merely establishing and defending the framework for market institutions' (Jessop 1999:2). Through systems of governance the state does not merely hand power over to the community, but it assumes an altered position so that 'power and interest are not simply rendered meaningless but are redefined and relocated' (Hajer and Wagenaar 2003:5). The new position of the state is such that it works in partnership with different interest groups to assist local action on a range of issues (Warner 2001). This is evident in public sector modernisation and reform processes that are occurring at a global scale (OECD 2005). Much of the stimulus for these changes is to lessen the state and achieve greater efficiency and accountability while also ensuring citizen involvement at a local level (Pemberton and Woods 2010).

Governance is thus characterised by the erosion of traditional boundaries, relying on new partners including the community, public and private sectors and based on devolved power (Rhodes 1997; Lowndes and Skelcher et al. 1996; Tendler 1997; Goodwin 1998; Murdoch and Abram 1998; Stoker 1998; Jones and Little 2000; Pierre 2000; Edwards et al. 2001; Pierre 2000; Gaventa 2004; and World Bank 2004). As state authority becomes redefined there is much more room for experimentation and diversity (Rhodes 2000). This is very much a potential or a possibility and as Jessop (1999) points out, success is not necessarily guaranteed. In other words creating these new structures does not ensure innovation or change, but it provides circumstances which encourage this very approach. This differs according to local contexts. For instance, in the US policy principles derived from market logics such as efficiency and autonomy are prized (Warner 2007). Equalities of opportunity are valued; equalities of outcome (for example, social inclusion) less so (Alesina and Glaeser 2004). Reshaped governance structures in the US fit encourage rather than mandate citizen participation in most local development programs. Conversely in Europe different political values are evident with the implementation of mainstreaming measures to ensure public bodies achieve a desirable level of participation in all of their activities (see for example Section 75 of the Northern Ireland Act 1998) alongside compulsory measures within specific programmes such as the European Rural Development Programme (CEC 2005). Much of the stimulus for participatory governance across Europe is to lessen the state and achieve greater efficiency and accountability while simultaneously ensuring citizen involvement at a local level 
(Pemberton and Woods 2010 online early JRS). Thus devolution in the US has had a somewhat different valence than that in Europe.

The combination of decentralisation and the reformation of political structures have thus resulted in participatory programmes assuming a central position in these regions as well as many other western economies (see for example, Furmankiewicz et al. 2010; Miraftab and McConnell 2008; Harwood and Zapata 2006; and Raco et al. 2006; Radin et al. 1996). The emerging framework has necessitated a paradigm shift from a top-down model of development to one which relies on a bottom-up, integrative approach. It relies on local assets and knowledge and has also placed pressure on tradition hierarchical administrative structures (OECD 2005). The literature would suggest that the capacity for communities to exercise genuine power is limited (Cooke and Kothari 2001; Hickey and Mohan 2004) and asymmetric power relations prevail (Skelcher et al. 1996; Campbell and Marshall 2000; Muir 2004 and Somerville 2005). The challenge of achieving participation appears to remain as governments across the globe embrace the principles of governance, each within localised contexts and raising questions of efficiency, effectiveness and equality. The rural development arena provides an example of a space where these new interactions between the state and partners from outside government are executed.

The literature suggests that governance structures are not always adequate for addressing local issues for a number of reasons. Perpetual questions have been raised in relation to the effectiveness of governance structures including the legitimacy of partnerships and of partners; power relations among partners; capacity building and predevelopment; weak consultation processes; participation; incoherence between layers of governance; lack of strategic direction and unrealistic time pressures (see for instance Shortall and Shucksmith 2001; Hayward et al. 2004; Scott 2004; Shortall 2005; Goodwin 2006; Connelly et al. 2006; Miraftab and McConnell 2008; Derkzen and Bock 2009; McAreavey 2009b; Furmankiewicz et al. 2010). Particularly in places where an uneven distribution of power has been durable, local governance may be less participatory, either formally or in practice (Dewees et al. 2003). Its mechanisms may replicate traditional power relationships or exacerbate them due to the retreat of unifying directives from the central state (Peterson 1981). Power according to Lukes relies on the capacity and the 
legitimacy to call on the obedience of others; it is about being able to influence the thoughts and desires of its objects without their being aware of its effects, so their real interests are suppressed. This goes beyond the second face of power identified by Bachrach and Baratz (1962) which encompasses overt and covert exclusion such as outright exclusion of particular groups or through control or manipulation of the agenda. So although individuals may have the capacity to exercise power; they may choose not to do so (Barnes 1988; Scott 2001; and Lukes 2005). In other words actors have options and choices that they are free to make in the pursuit of their particular interests. If it is the case that 'a community understands its own problems through frameworks that are in fact inadequate to address its own goals' (Ron 2008:4) then difficulties are likely to persist in relation to the ability of partners to participate in a meaningful way in rural development actions.

\section{Participating in rural development}

In the Future of Rural Society, the European Commission outlined its fundamental approach to rural development (CEC 1988). This was significant, not least because it paved the way for a major reform of the CAP and highlighting the need for restructuring of agriculture alongside protecting the environment. Furthermore it indicated a new social agenda and the political direction for Europe as it placed emphasis on achieving social and economic cohesion. This marked a major transition in agricultural policy, shifting from a sectoral to a territorial basis, placing emphasis on economic diversification while also encouraging integrated, endogenous rural development.

Not long after publication of its seminal policy, the LEADER initiative was introduced by the Commission in 1991 as a major community initiative aimed specifically at rural development. It represented not only a commitment to rural (as opposed to agricultural) development but a very new policy style. LEADER included the unique combination of small, local groups; innovative development projects and flexible funding (Ray 1998). The policy rhetoric was one of empowerment, participation, community, capacity building, partnership, innovation and finally knowledge/ experience transfer as the initiative was considered a rural laboratory (Sivenas 2006). It allowed a 
territory to cultivate its own 'development repertoire' paying attention to the specificity of that area including food, craft, language and dialect, landscape and music' (Ray 1999:525). Despite policy rhetoric of community capacity building and involvement the LEADER approach has provoked broader questions concerning the governance approach including the legitimacy of local partnerships; representation; economic versus social objectives and power relations (see for example Storey 1999; Ray 2000; Shortall and Shucksmith 2001; Scott 2002, 2004).

Past problems notwithstanding, it is significant that the LEADER approach has been mainstreamed under this European Agriculture Rural Development Fund. The priority on a social welfare agenda therefore remains in these most recent reforms of the Common Agricultural Policy (CAP), Agenda 2000. Pillar One of the CAP is concerned with agricultural market support and direct payments, namely the Single Payment Scheme (CEC 2005). Pillar Two refers to expenditure under the new Rural Development Regulation (RDR) and is aimed at improving the competitiveness of agriculture and forestry while achieving environmentally sustainable land management and also diversifying rural economic activity (Council Regulation (EU) No. 1698/2005). The majority of agricultural subsidies are now decoupled from the level of production (single farm payment) and linked to good agricultural and environmental practice (crosscompliance). In addition, direct farm payments will be reduced over time (modulation) with monies redirected to finance rural development (CEC 2005). CAP is therefore no longer an agricultural policy; to the contrary rural development has increased in prominence and importance (Petit 2008). Indeed opportunities exist for non-farmers to access these funds, including non-profit organizations and rural businesses.

In the US, most rural development policy and funding is managed through the Department of Agriculture; USDA Rural Development programs help with low interest loans and grants for housing, water and wastewater systems, community facilities, energy projects, and business development (USDA, 2009). Nonprofit organizations, rural businesses, and public bodies-or their partnership groups-generally apply for direct loans or grants, which state offices award through the Rural Empowerment Program, the Rural Economic Area Partnership, and the National Rural Development Partnership. These governance mechanisms within the US have frequently helped create vibrant 
growth poles that incorporate significant citizen participation in planning. For example, through the successful federally-funded Resource Development and Conservation Program (RDCP), state rural development councils are encouraged to reflect membership from five partnership groups: federal officials, state officials, local government, tribal representatives, and the private sector (Radin et al. 1996). Other forms of development funding provided by the federal government (such as Community Development Block Grants) require states to create space for public input on locally-implemented projects. These participatory efforts can reshape the economic terrain of broad regions; a good example is the state of Vermont which has been transformed from an agricultural backwater to a center of the booming local agriculture movement through the work of public-private partnerships like the Vermont Council on Rural Development (Radin 2001).

Evidence also shows that these bright spots have been unevenly distributed throughout rural space and the citizen "empowerment" envisioned in the shift to devolution has not been uniformly attainable. This is in part because most of the funding flowing to rural communities comes from USDA in the form of commodity-related subsidies and conservation payments for producers (Whitener and Parker 2007). The focus on commodity support means that, unlike Europe, rural development policy in the US lacks a "multi-functional link that effectively connects it to broader rural development and environmental objectives” (Warner and Shortall 2008: 1). Thus despite growing goals of participation, economic interests like growth coalitions and producer lobbies, may continue to dominate rural governance (ibid.). This may be especially true in high poverty areas with low levels of human capital and unequal access to power and resources perhaps because social inclusion and economic equity are not stated policy goals as in the EU. Even where participation is strongly encouraged as with the RDCP, there is much state level variation with some councils extending membership to any interested elected officials and others presenting considerable barriers to heterogenous participation (Radin et al. 1996). With the increased focus since the 1980s on block grants to states (such as the Empowerment Zones/Enterprise Communities program, which makes grants for tax credits and other supply-side incentives for business investment (Reid 1999)), the growth of a competitive development ideology within local 
government has further deemphasized equity as a central consideration (Donahue 1997).

Without structured mechanisms in place in the US, opportunities for participation, ostensibly provided through devolution, may be less available in practice. Decreased regulation and directive from the central state can leave a power vacuum easily filled by traditionally dominant group. This in turn can exacerbate existing imbalances: communities with resource inequalities may defer to elites to plan and carry out policies that would bring much needed investment quickly, which at the sub-national level typically requires maximizing capital inflow and minimizing redistribution (Peterson 1981; Gunderson et al. 2004). Even in a European context of equality and inclusion, there is evidence of dominance of elite interests with the state agenda permeating regeneration initiatives, often without attention given to wider community interests (Cornwall 2004; Williams 2004; Taylor 2007; McAreavey 2009a, 2009b).

And so questions remains: in what exactly are the partners of rural governance participating? How much power are they afforded? To what extent are they able to exercise change within structures of governance? Are some types of participation more appropriate than others? How do the different contexts impact on power relations among rural development actors?

\section{The USA context: Alabama}

The southern US has a history of spatial inequality and most of the country's persistent poverty counties are located here (Kusmin 2008). The southern states were some of the strongest advocates for devolution during the Reagan Era, with a long history of demand for states' rights and the relaxation of mandates tied to federal aid (Sanders 1999); political culture tends to be traditionalistic-individualistic (emphasizing traditional authority and protection of private interests) (Elazar 1994). Alabama is in many ways an ideal-typical state for this region. Its government is particularly small: it consistently ranks in the bottom 5 US states in terms of per-capita taxation. Human capital is also quite low: the state also consistently ranks in the bottom 5 or so for per-pupil expenditures, median household income, and bachelor's degree attainment (US Census 2008). 
The state's economic development agenda has long been dominated by a smallgovernment framework focusing on capital subsidy primarily through low tax rates and low labor costs (Rork 2005). With the increasing entrepreneurialism enabled by new governance processes, innovative multi-level partnerships between state government and transnational companies were formed during the 1990s and helped generate a number of new urban and suburban jobs particularly through recruitment of foreign auto manufacturers. The AlabamaGermany Partnership, for example, facilitated valuable relationships between German firms, state officials, and local workforces. Other partnerships, such as the Economic Development Partnership of Alabama, provided a space for support businesses (such as technical support or warehousing), state workforce training programs, and employers to interact. These new governance structures had dynamic results for many local economies and were key in establishing a level of endogenous development within a state that had long grappled with a stagnant industrial profile.

However, in the late 90 s and early 00s, the state faced a number of budget crises as well as troubling economic trends like the overseas exodus of traditional industries and the accelerating competitiveness of workforces in neighboring states like Florida and Georgia. While wealthier suburban locales were benefiting from new partnerships and investments, other institutional structures with deep historical roots prevented these economic flows from benefiting the state as a whole. In particular, the state constitution (created by landowning elites in the post-Civil War era) codified anti-regulationist principles that made Alabama an attractive location for foreign manufacturing firms, but it also lacked basic mechanisms that would ameliorate the inevitable social contradictions of growth. An extremely regressive system of taxation (weighted heavily on the sales tax), a lack of county home rule, and a highly earmarked budget are the key elements of this institutional structure (Permaloff and Grafton 2008). The tax arrangement meant that revenues from wealthy areas would not be shared with poor (often rural and black) local schools and governments. The lack of county home rule meant that legislative "gatekeepers" would determine what local policy goals were accomplished. And, the earmarked budget (about $87 \%$ of revenue) meant that new social demands would not find support or accommodation. As a result, historically disadvantaged areas continued to 
slide relatively further backward in terms of publicly-funded human development factors such as educational attainment. Poor schools, few amenities, and inferior jobs opportunities (especially in the "Black Belt," twelve contiguous counties with majority African American populations) contributed to a persistent cycle of rural underemployment and low endogenous development capacity.

This key aspect of the state's institutional structure was durable for a number of reasons. It maintained long-standing power relationships even in times of economic prosperity, when capital influxes should have been converted to more stable economic bases such as human capital investment (Rork 2005). It also reproduced perceptions of the proper distribution of power between state, market, and community: for maximum civic freedom, the state should be tightly bounded and free market processes privileged (a key neoliberal tenet, Peck and Tickell 2002). As a result, collective ideologies emphasized trust in market elites and mistrust in or resignation toward the existing governance structure, all of which further stymied citizen empowerment. Economic elites also had an instrumental role in maintaining these conditions; it was widely acknowledged that certain groups-particularly powerful rural interests like large agricultural and timber landowners and their lobbies-systematically influenced the policy behavior of local legislators and voters both directly and indirectly.

During the late 1990s and 2000s the state government became concerned by these issues of spatial inequality and the minimal opportunities and capacities available in much of rural Alabama and considered a number of modernizing reforms to address spatial inequality through education investments and a moderately progressive reshuffling of the tax code. However, given the conservative partisan and ideological commitments of these leaders, increasing capacities in lagging areas was not seen as an emancipatory end in itself, but was seen exclusively as a means to create or attract economic growth. A more educated rural workforce would make these areas more appealing to employers and might ideally make them net contributors to rather than net drains on state resources. Proposed reforms to existing governance structures aimed to break up some of these entrenched relationships of power and influence because their macroeconomic effects had finally become apparent to state government.

However, even in their ambitiousness, the programs which the state proposed in an 
attempt to ameliorate unevenness still hewed to very similar power frameworks. These were "hard" reforms administered from the state level in a top-down manner; few aspects of these development policy proposals would have actually brought participatory agency down to the level of local communities or enabled endogenous development as understood through current scholarly consensus: "valorizing and exploiting local resources...and [emphasizing] local participation in the design and implementation of action...therefore implying radical changes in the mode of governing” (Furmankiewicz et al. 2010: 53). This may be because the institutional and cultural context that maintains an uneven distribution of resources over the Alabama landscape (as discussed above) also sets up significant obstacles to bottom-up development. With an inflexible budget and low tax revenues, public infrastructural investments such as broadband access and public transportation are lacking, which prevents local people from pursuing available education and training opportunities and from establishing or nurturing valuable social and economic networks outside of their immediate communities. Human capitals are often low due to poor local education opportunities and few skilled in-migrants, meaning a dearth of many of the civic and entrepreneurial capacities important to endogenous development efforts. None of the targeted policies that researchers have identified as key to facilitating endogenous development (Radin et al. 1996)—promoting local government cooperation, allowing jurisdictions to share locally generated tax revenues, promoting local land-use planning, establishing training for civic leaders-were proposed during this period. Research by Dewees et al. (2003) in the state of Ohio suggests that these circumstances are part of a broader pattern whereby US counties most disadvantaged by changing macroeconomic conditions tend not to be able to make use of the communityled development opportunities that new governance structures were supposed to facilitate.

The local dependence fostered by Alabama's governance structure and its dominant capital-subsidy paradigm has prevented communities from even conceptualizing development as a bottom-up process. The rhetoric of "job deliverance" has dominated speech from public officials for decades, and the publicity afforded successful industrial recruitments saturates the media. Subsidies for exogenous employers (tax abatements, workforce training, site preparation, etc.) — even smaller ones-are not matched by subsidies for home-grown employers. State disbursements of federal development 
funding appear to favor capital investments over community projects (for example, 71\% of the 2009 block grants disbursed to Alabama counties, towns, and cities went to sewer, streets, and drainage projects; only $22 \%$ went to establishment or revitalization of community resources like senior centers, parks, or libraries (ADECA 2009)). Rather than an isolated incident, this data may corroborate previous evidence on state tendencies to assist local governments rather than community organizations, which were the intended beneficiaries in some of the programs being replaced by block grants; in such cases, "underserved constituents were often missing or under-represented on boards overseeing how funds were used locally” (Reeder 1996:3).

Because the logics of endogenous development are framed in top-down terms and through market rationality themes like "economies of scale,” the ideas of creating jobs through local enterprise, or of building community capacities that are not connected to immediate economic benefits, are less familiar and possibly seen as inefficient, not only by state and market elites, but also-judging from the widespread lack of demand for enabling governance structures-by local communities themselves. Despite popular rhetorics of market rationality, equality of opportunity, and self-reliance, these circumstances continue to justify continued perceptions of public investment in disadvantaged areas as a "waste.” Currently, most of the top-down reforms that were proposed to break up stagnant relationships of economic inequality have been defeated in referenda through aggressive campaigns by elite opponents such as the agriculture lobby. Without any parallel state attempts to build endogenous development capacities, many rural communities appear to be in much the same place as they were twenty years ago despite the success of partnerships and new governance mechanisms in the capital subsidy sphere of development.

\section{The European context: Northern Ireland}

Many rural development partnerships exist within Northern Ireland reflecting a multiscalar governance approach. Some, such as the European INTERREG programme promoting territorial co-operation across border regions, are found across Member States. Others are distinctive to Northern Ireland and reflect circumstances particular to that 
region. For example under new legislation emerging from the Good Friday Agreement (North/South Co-operation (Implementation Bodies) (Northern Ireland) Order 1999), six cross-border non-departmental public bodies were established 'to implement policies agreed by Ministers in the North/South Ministerial Council and to develop cross-border co-operation on practical matters of mutual concern'. Meanwhile the Special European Union Programme Body was created to administer EU funded programmes, including the European Programme for Peace and Reconciliation (i.e. the PEACE programme). PEACE funding is typically awarded to larger public bodies who, as intermediary agents, distribute the monies to smaller community and voluntary sector based organisations. PEACE is not a rural development programme per se, but because it specifically includes the border region with the Irish Republic, geography means that it corresponds to some of the most rural areas of Northern Ireland. Meanwhile the International Fund for Ireland (IFI) is funded by the USA, the European Union, Canada, Australia and New Zealand and, like the PEACE programme, operates in Northern Ireland and the border counties of Ireland. Its objective is also to encourage peace and reconciliation through economic and social development. Both PEACE and the IFI represent funding sources for rural development activities that complement Europe's mainstream fund that exists within the current Common Agricultural Policy (CAP). The success of each of these initiatives is reliant on the participation of local communities and the CAP provides an example of how participation is a limited affair.

Although operating within a common rural development policy, each member state retains considerable control. For example, each state is obliged to draw up a seven-year rural development plan at a geographic level that it deems appropriate. Activities are drawn from a list of thirteen set out in Article 33 of the Rural Development Regulation and include traditional agricultural actions as well as broader rural development measures including development of villages; protection and conservation of the rural heritage; and farm relief services. This provides a framework for the allocation of funds, sourced from the EU and matched by the member state. The implementation of these national rural development plans, such as the Northern Ireland Rural Development Programme (NIRDP), is reliant on Local Action Groups that adopt the LEADER approach 'including partnership capacity, implementation of local strategies, cooperation, networking and 
acquisition of skills' (CEC, 2005:6(50)). These partnerships devise area based strategies from which individual projects are funded and comprise representatives from the voluntary and community; public; and private sectors. The programme very neatly epitomizes the governance approach that is evident globally within the new rural paradigm (OECD 2006).

From an EU budgetary perspective RDR funding is approximately 10 percent of the CAP budget but there is potential to increase this through modulation. Modulation refers to the ability of member states to use money saved on direct agricultural subsidies (Pillar One) to be transferred to rural development and environmental schemes (Pillar Two) (CEC, 1998). Compulsory modulation has been applied across the EU since 2005, set initially at four percent and increased to five percent from 2007. The UK and Portugal also secured EU agreement for an additional voluntary national modulation rate (Lowe et al., 2002), up to a rate of 20 percent, to be applied. In England this will see the overall modulation rate (EU and additional national rate) rise to 19 percent from 2009. This has been deemed necessary to fund national agri-environmental schemes including the new Entry Level Stewardship. However, the rules for additional voluntary modulation allow each devolved region within the UK to set rates according to their own rural development needs and priorities. This sees the Northern Ireland overall modulation rate rise to 12 percent in 2009 (compared to 9.2 percent in Wales and 13.5 percent in Scotland) (Defra website accessed 31/ 10/2008). However, it could be argued that by capping voluntary modulation below (at 4.5 percent in the past and currently at a maximum rate of 14 percent for England) the 20 percent rate permitted by the EU (House of Commons, 2002) the UK (including its devolved regions) are offering a hollow nod in the direction of reform lobbyists. Significant also, national modulation is driven by a need to fund agrienvironmental schemes. For example, up to 80 percent of voluntary modulation will be allocated to thematic axis 2 (improving the environment and the countryside). Over the seven years of the Rural Development Programme voluntary modulation is earmarked for funding of $£ 180$ million by the Northern Ireland Assembly (Farmers Journal, 2007).

Simultaneously the Review of Public Administration in Northern Ireland aims to strengthen the role of local government so that 'under the new system councils will have responsibility for a wide range of functions and a strong power to influence a great many 
more. This will enable them to respond flexibly to local needs and make a real difference to people's lives ... and through community planning the opportunity exists to promote good relations, address poverty and environmental issues, and develop normal civic society’ (NI Executive 2006:8). The Review of Public Administration is essentially about aligning administrative boundaries so that public services can be delivered more effectively. Meanwhile participatory governance is embedded within the new councils. Part of their enhanced functions includes responsibility for rural development; urban and rural regeneration; and community planning. This latter role 'will require the council to consult all its constituents about issues that affect their lives and allow people to have a say in the way in which their area is developed...Councils will not necessarily directly deliver all the services for which they are responsible. They will be encouraged to develop partnership arrangements with the voluntary and community sectors, and the private sector in developing and commissioning services' (Northern Ireland Executive 2006:7).

This emerging structure is being super-imposed on an already cluttered rural development space.

The Department of Agriculture and Rural Development (DARD) as the central government body co-ordinating the rural development programme in the region, originally intended that the boundaries of the LAGs would be 'co-terminus' with the new councils. However the new Northern Ireland administrative (council) boundaries have not yet been implemented due to the ongoing implementation of the Review of Public Administration (NI Executive 2008). Hence the creation of seven LAGs has been made more complicated as existing councils have come together to form clusters. The example of the North East area illustrates the different stages of this process. The newly formed LAG has 30 members of which 15 are from statutory and government bodies and 15 represent social and community organisations. The council cluster (in this case five: Ballymena, Ballymoney, Coleraine, Larne and Moyle) nominated elected representatives to the LAG. Individuals were able to apply to this North East area council cluster for a place as a social partner using application forms (designated by DARD). Following the scoring of each application using criteria devised by the council cluster with guidance from DARD, an open meeting was then held to seek agreement on the 15 social and 
community partners. Individuals were scored, and therefore their suitability assessed, on a number of issues including skills and experience in financial appraisal, economic development, programme delivery and business planning (DARD 2007). In theory an area could have had more than one LAG competing to deliver the programme. In addition the council clusters were required by DARD to have clear scoring criteria and to actively promote equality of opportunity for all interest groups (in line with Section 75 of the Northern Ireland Act 1998). DARD subsequently approved a LAG for each area. In partnership with the council cluster, the approved LAG is responsible for developing and implementing a local rural development strategy that addresses the measures outlined within Axis three of the NIRDP 2007-13. This will complement the NI wide programme. Publicity material asserts that the council cluster is financially and administratively responsible for the funds and for the operation of the local LAG, but significantly the contract for local programme implementation and delivery is between DARD and a lead council that has been agreed by the cluster (DARD 2007). Meanwhile funding is paid directly from DARD to the relevant project; the council clusters are not involved. Broadly then, the LAGs role is to assist with animation of the area, and to co-operate with, and make recommendations to, the council cluster. It has neither legal nor financial responsibilities. Meanwhile a single council is legally responsible for delivering the programme.

\section{Discussion}

These case studies suggest that institutional frameworks for rural development can hinder community empowerment even where central state authority is tightly bounded and devolved governance mechanisms have taken hold. In both cases, "state projects and strategies rest on a prior... identification of suitable objects of intervention and activity" to describe the social, political and cultural characteristics of a created space (Pemberton and Woods 2010:5), that is the rural development arena. These are not necessarily 'popular spaces' that emerge from within and are defined by the community; they are instead 'invited spaces' that are conceptualized by the state and into which communities are invited (Cornwall, 2004). But this is only part of the story: Foucault (1982) argues 
that power operates through social systems rather than at a personal level with individual practices suggested by culture, society and social group. Power relations within rural governance are complex and uneven. Actors have agency, they are not entirely impassive recipients of state action; they have particular experiences, interests and beliefs, all of which affect how and where they choose to act (Hay 2002; Bevir and Rhodes 2006).

LAG members within NIRDP have the capacity to exercise power firstly through the act of participation as this ensures that DARD complies with European program requirements. There is the prospect for LAG members to exert further power, albeit within the bounds of the rural development framework, as they are responsible for stimulating local development and also for making recommendations to the council clusters. However, these individuals are not able to alter the boundaries of action and thereby affect change through this channel. Furthermore the field of what is possible is ultimately determined by central government and by the European Commission, and to a lesser extent by the local council cluster. Although individuals were able to become involved in the LAG (subject to meeting certain criteria), they were not able to participate in the restricted decision making realm that existed across the different levels of governance such as within the council cluster. Decisions were confined to specific, predefined issues; 'real' interests were not necessarily identified. In this sense hidden power was evident as those outside control were not only omitted from the political process but they were denied entry (Lukes, 2005).

In the US case, the efficiency imperative more overtly shaped rural development agendas and "processes" appear collectively deemed less important than "product." Attempts to increase rural development capacities were envisioned and imposed in a topdown manner, suggesting that traditionally disadvantaged communities continued to be objects rather than subjects of development. To paraphrase Lagendijk, as it is the state's 'imaginaries' of rural space that define the subjects and objects of development, it also shapes the strategies and actions that emerge (2007:1199); displaying the ideology and dominance of the elite (Mills 1956). In other words the way in which the state understands development affects the ultimate outcomes. If, as in the case of Alabama, the product is imperative then at the very most, lip service is paid to process issues. Though devolution aims to bring government closer to citizens, state structures like the state 
constitution maintain certain distributions of power. Low expectations around local communities' ability to produce effective economic outcomes legitimate these distributions of power.

Furmankiewicz et al. (2010) observe a similar pattern in rural Poland whereby local enterprises, perceived by officials as incapable, were "supported" by organizational guidelines that actually constrained their endogenous development efforts. As in Northern Ireland and in Alabama, elite-defined norms and agendas are continually maintained. So while the NIRDP has the indicators of an exogenous and integrated approach, there is a danger that old criticisms of emphasis on product over process will re-emerge. Already much emphasis has been placed on establishing the correct framework for ensuring financial and operational rigor. For example the Farm Family Options measure within the NIRDP did not open until November 2009 due to delays with DARDs approval of the Economic Appraisal and Audit Queries (personal communication with staff). The framework within which regeneration initiatives actually operate in both cases examined in this chapter would appear to be allied to systems of managerial control or established authority rather than to processes of community empowerment (Raco and Imrie 2000). Statutory agencies retain power over individual rural development actors as they set out and implement the terms of engagement, supporting the opinion that the rules of engagement rest firmly with the elite (Bochel 2006). The programs exhibit further elitism as the power of the ruling class is reinforced through recreation of their structures, norms and process. In other words there was little debate around how rural development programs are to be delivered. The very means by which interaction occurs is shaped by statutory agencies, oftentimes with other partners of governance oblivious to this manipulation and control. The inherent assumption of organisational superiority is a symptom of the privileged ruling stratum; it is part of the ideology of the elite (Mills 1956; Katz 1975). It follows that this elite shapes the very nature of ensuing action and creates a privileged regeneration community (McAreavey 2009a).

These critical explorations of the extent to which participation is actually achievable given varying governance structures are important because rural local governments in both regions have been tasked with considerable responsibility for regeneration (HM Treasury 2007, Reese 1994; OECD 2006; CEC 2005). If local people and knowledges are 
to be formally valued as much as higher-level economic forces (such as macroeconomic policies coming from the central state) the continued operation of traditional and/or hidden power relationships should be acknowledged. Because the state itself "has no power-it is merely an institutional ensemble" that "reflects the prevailing balance of forces” (Jessop 1990 as quoted in Pemberton and Goodwin 2010: 3), limiting the state does not necessarily change the balance of economic or social forces; interventions in the third dimension of power where agendas are set and processes of inequality normalized (Lukes 2005), would be appropriate but ambitious. Otherwise full participation in the sense that Arnstein describes will remain an elite privilege-not only through boundaries to access but through dominant discourses that limit communities' understanding of their agency. This arrangement limits capacities to bring about change but also, in the Foucauldian sense, to shape what is possible.

But as Derkzen et al. (2008) remind us, asymmetrical power relations are perhaps less of a problem than we might think. Is it appropriate for individuals or groups without professional experience in development work to be granted responsibility for skilled tasks such as financial monitoring and budget prioritizing? Do communities want these responsibilities where "product"-rural regeneration-is an economic need of the first order? Equally, questions must be asked about the ability of statutory agencies to effectively identify and engage with interested parties within a particular territory. At the end of the day much of the imperative for participatory governance is to achieve greater efficiency and effectiveness; ultimately rural development actors do not aspire to realizing seismic power shifts. Mass participation is unlikely to deliver greater efficacy; instead strategic participation would be inclined to have more relevance. At the least, greater reflexivity by policymakers and multi-level partners might help keep the positive rhetoric of participation grounded in the complex reality of its application. The challenge remains for players in this new rural paradigm: how to transcend artificiality, secure meaningful engagement while creating space for the articulation and implementation of a community agenda? 


\section{References}

Adams, D. and Hess, M. (2001) Community public policy: Fad or fountain? Australian Journal of Public Administration Vol. 60 No.2 pp.13-23.

Alabama Department of Economic and Community Affairs (2009). PY 2009 Funded Projects List for Small City, Large City, County, and Community Enhancement Funds. Accessed 2/02/10 at http://www.adeca.alabama.gov/C12/Late\%20Breaking\%20News/Document\%20Libr ary/_1019092201_001.pdf

Alesina, A. and Glaeser, E. (2004) Fighting Poverty in the US and Europe: A World of Differences. New York: Oxford University Press.

Arnstein, S. (1969) A ladder of citizen participation. Journal of the American Institute of Planners, Vol. 35 No.4 pp. 216-224.

Ayres, S and Pearce, G. (2008) Transforming regional governance in Europe. Policy and Politics Vol. 36 No. 4 pp. 539-44.

Bachrach, P. and Baratz, M. (1962) The two faces of power. American Political Science Review 56: 947-52.

Barnes M., Newman, J., Knops, A. and Sullivan, H. (2003) Constituting 'the public' in public participation. Public Administration, Vol. 81.2 pp. 379-399.

Barnes, B. (1988) The nature of power. Cambridge: Polity Press in association with Oxford: Basil Blackwell

Bevir, M. and Rhodes, R. A.W. (2006) Defending interpretation. European Political Science 5 pp. 69-83.

Blair, T. (1994) Sharing responsibility for crime, in Coote, A. (ed.) Families, children and crime. London: IPPR, p.90.

Bochel, C. (2006) New Labour, participation and the policy process. Public policy and administration. Vol. 21 No. 4 pp.10-22.

Bourdieu, P. (1986) The forms of capital in Richardson, J.G. (ed) Handbook of theory and research for the Sociology of education Westport, Connecticut: Greenwood Press pp.241-258.

Callanan, M. (2005) Institutionalizing Participation and Governance? New Participative Structures in Local Government in Ireland. Public Administration Vol. 83 No. 4 pp. 909-929. 
Coleman, J.S. (1990) Foundations of Social Theory, Cambridge, MA: Belknap Press

Commins, P. (2004) Poverty and Social exclusion in rural areas: characteristics, processes and research issues. Sociologica Ruralis Vol. 44 No. 1 pp 60-75.

Commission of the European Communities (CEC) (1988) The future of rural society, Brussels: Commission (88) 601, Final/2.

Commission of the European Communities (CEC) (1998) Agenda 2000: commission proposals. Brussels: Commission (98) 158, Final.

Commission of the European Communities (CEC) (2005) COUNCIL REGULATION (EC) No 1698/2005 on support for rural development by the European Agricultural Fund for Rural Development (EAFRD) OJ L277 pp. 1-40.

Cornwall, A. (2004) New democratic spaces? The politics and dynamics of institutionalised participation. IDS Bulletin, Vol. 35 No.2, pp.1-10.

Department of Agriculture and Rural Development in Northern Ireland (2007) Guidance for selection of local action groups and submission of funding bids. Belfast:DARD

Derkzen, P., Franklin, A., and Bock, B. (2008) Examining power struggles as a signifier of successful partnership working: A case study of partnership dynamics. Journal of Rural Studies Vol. 24, No. 4, pp. 458-466.

Derkzen, P. and Bock, B. (2009) Partnership and role perception, three case studies on the meaning of being a representative in rural partnerships. Government and Policy Vol. 27 No.1 pp.75-89.

Dewees, S., Lobao, L., and Swanson, L. (2003) Local economic development in an age of devolution: The question of rural localities. Rural Sociology 68(2): 182-206.

Donahue, J. D. (1997) Disunited States. New York: Basic Books.

Durkheim, E. 1984 (1893) The Division of Labor in Society. New York: Free Press.

Edwards, B., Goodwin, M., Pemberton, S. and Woods, M. (2001) Partnerships, power, and scale in rural governance Environment and Planning C: Government and Policy, Vol. 19No. 2 pp.289-310.

Elazar, D. (1994) The American mosaic: The impact of space, time, and culture on American politics. Boulder, CO: Harper \& Row.

Foucault, M. (1982) Afterward: the subject and power. Pp. 208-226 in H.L. Dreyfus and P. Rabinow Foucault: beyond structuralism and hermeneutics. Chicago, IL: The University of Chicago Press. 
Furmankiewicz, M., Thompson, N., and Zielinska, M. (2010) Area-based partnerships in rural Poland: The post-accession experience. Journal of Rural Studies 26: 52-62.

Gaventa, G. (2004) Towards participatory governance: assessing the transformative possibilities. In Hickey, S. and Mohan, G. (eds) Participation: from Tyranny to Transformation? London and New York: Zed books pp. 25-42.

Goodwin, M. (1998) The Governance of Rural Areas: Some Emerging Research Issues and Agendas. Journal of Rural Studies Vol. 14 No. 1 pp.5-12.

Goodwin, M. (2006) Multi-level governance in rural UK: recent debates. Paper presented to ESRC New Rural Economies Seminar Series 13/01/06.

Gunderson, C., Kuhn, B., Offatt, S., and Morehart, M. (2004) A consideration of the devolution of federal

agricultural policy. Agricultural Economic Report No. 836, Economic Research Service, USDA. Accessed 2/28/10 at http://www.ers.usda.gov/publications/aer836/aer836.pdf.

Hajer, M.J. and Wagenaar, H (2003) Introduction in Hajer, M.J. and Wagenaar, H. Deliberative policy analysis. Understanding governance in the network society pp.130 .

Harwood, S. A., and Zapata, M. (2006) Preparing to Plan: Collaborative Planning in Monteverde, Costa Rica. International Planning Studies, 11 (3-4): 187-207.

Hay, C. (2002) Political Analysis: A critical introduction. Palgrave: Basingstoke.

Hayward, C., Simpson, L. and Wood, L. (2004) Still left out in the cold: Problematising participatory research and development. Sociologia Ruralis Vol. 44.1 pp.95-108.

Hickey, S. and Mohan, G. (2004) Towards participation as transformation: critical themes and challenges, in S. Hickey and G. Mohan (eds) Participation: From Tyranny to Transformation pp. 3-24. London: Zed books.

HM Treasury (2007). Sub-national review of economic development and regeneration. London: HM Treasury.

Jessop, B. 1999. The dynamics of partnership and governance failure. In: Stoker, G. (Ed.), The New Politics of Local Governance in Britain. Oxford: Oxford University Press.

Jones, O. and Little, J. (2000) Rural Challenge(s): partnership and new rural governance. Journal of Rural Studies, Vol. 16 No.2 pp.171-183.

Kusmin, L. (ed.), 2008. Rural America at a glance. Economic Information Bulletin No. EIB-40, Economic Research Service, USDA. Accessed 12/03/09 at 
http://www.ers.usda.gov/Publications/EIB40/EIB40.pdf.

Katz, M.B. (1975) Class, Bureaucracy and Schools: The illusion of educational change in America. New York: Berger

Lagendijk, A. (2007): The accident of the region. A strategic relational perspective on the construction of the region's significance. Regional Studies 41 (9) 1193 -1208

Lowe P., Buller, H. and Ward, N. (2002) Setting the next agenda?: British and French approaches to the second pillar of the Common Agricultural Policy, Journal of Rural Studies Vol.18 No.1 pp. 1-17.

Lukes, S. (2005) Power: A Radical View (2 ${ }^{\text {nd }}$ edition). Basingstoke, Palgrave Macmillan, 2005.

Marx, K. (1959) Economic and Philosophical Manuscripts of 1844 Moscow: Progress Publishers, available online at http://www.marxists.org/archive/marx/works/1844/manuscripts/preface.htm (last accessed 18.07.07)

McAreavey, R. (2009a) Community Regeneration: An Elite or a 'Real' Community Space? International Planning Studies, Volume 14(3) pp. 311 - 327

McAreavey, R. (2009b) Rural Development Theory and Practice: A critical analysis of rural development theory and practice London and New York: Routledge.

Mills, C.W. (1956) The Power Elite. New York : Oxford University Press.

Miraftab, F. and McConnell, E. D. (2008) Multiculturalizing Rural Towns-Insights for Inclusive Planning. International Planning Studies Vol. 13, No. 4, pp.343-360.

Molotch, H. (1976) The city as a growth machine: Toward a political economy of place. American Journal of Sociology, Vol. 82, No. 2, pp. 309-332.

Muir, J. (2004) Public participation in area-based urban regeneration programmes. Housing Studies, Vol. 19 No. 6 pp.947-66.

Murdoch, J. and Abram, S. (1998) Defining the Limits of Community Governance. Journal of Rural Studies, Vol.14 No.1 pp.41-50.

Northern Ireland Executive (2006) Better Government for Northern Ireland. Belfast: RPA (http://www.rpani.gov.uk/) Accessed 16.11.06.

NI Executive 2008 - Gildernew confirms RDP council clusters, 21 March 2008. http://www.northernireland.gov.uk/news/news-dard-210308-gildernew-confirmsrdp, last accessed 04.03.10. 
Northern Ireland Rural Development Programme 2007-2013 (2007) Belfast: Department of Agriculture and Rural Development.

OECD (2001) Local Partnerships for better governance. Paris: OECD.

OECD (2005) Modernising Government. The Way Forward. Paris: OECD.

OECD (2006) The new rural paradigm. Policies and governance. Paris: OECD.

Somerville, P. (2005) Community governance and democracy. Policy and Politics Vol. 33.1 pp.117-144.

Park, R.E. (1952) Human communities: the city and human ecology. Glencoe III: Free press.

Peck, J. and Tickell, A. (2002) Neoliberalizing space. In Brenner and Theodore (eds.), Spaces of Neoliberalism: Urban Restructuring in North America and Western Europe. Oxford: Blackwell Publishers.

Pemberton, S. and Goodwin, M. Rethinking the changing structures of rural local government - State power, rural politics and local political strategies? In Press, Corrected Proof, Available online 22 January 2010

Permaloff, A. and Grafton, C. (2008) Political Power in Alabama: The More Things Change...University of Georgia Press, Athens, GA.

Peterson, P.E. (1981) City Limits. University of Chicago Press, Chicago.

Petit, M. (2008) The CAP After Fifty Years: A Never-Ending Reform Process. EuroChoices Vol. 7, No.2 p. 44.

Pierre, J. (2000) Introduction: understanding governance in Pierre, J. (ed.) Debating Governance: authority, steering and democracy. Oxford University Press pp.1-12.

Portes A. (1998) Social Capital: Its origins and applications in modern sociology. Annual Review of Sociology Vol. 24 pp. 1-24.

Putnam, R.D. (1993) The Prosperous Community. The American Prospect Vol. 4 no. 13.

Raco, M. and Imrie, R. (2000) Governmentality and rights and responsibilities in urban policy. Environment and Planning A Vol. 32 Vol. 12, pp.2187-2204.

Raco, M., Parker, G., and Doak, J. (2006) Reshaping spaces of local governance? Community strategies and the modernisation of local government in England. Environment and Planning C: Government and Policy Vol. 24 No.4 pp.475 - 496. 
Radin, B., Agranoff, R., O’Bowman, A., Buntz, C.G., Ott, J.S., Romzek, B.S., and Wilson, R. H. (1996) New Governance for Rural America: Creating Intergovernmental Partnerships. Lawrence KS: University Press of Kansas

Radin, B. (2001) State rural development councils are creating public-private partnerships. Rural Development Perspectives 11(2), Economic Research Service, USDA. Accessed 2/05/10 at http://www.ers.usda.gov/publications/rdp/rdp296/rdp296a.pdf.

Ray, C. (1998) Territory, structures and interpretation. Two case studies of the European Union’s LEADER I programme. Journal of Rural Studies Vol.14 No.1, 79-87.

Ray, C. (1999) Endogenous development in an era of reflexive modernity. Journal of Rural Studies Vol. 15 No.3, pp. 257-267.

Ray, C. (2000) The EU LEADER Programme: rural development laboratory Sociologia Ruralis Vol. 40 No.2 pp. 163-172.

Reeder, R. (1996) How would rural areas fare under block grants? Agricultural Information Bulletin No. 724-03, Economic Research Service, USDA.

Reese, L. (1994). The role of counties in local economic development. Economic Development Quarterly 8: 28-42.

Reid, J.N., 1999. Community empowerment: A new approach for rural development. Rural Development Perspectives 14 (1), Economic Research Service, USDA. Accessed 2/05/10 at http://www.ers.usda.gov/Publications/RDP/RDPMay99/RDPMay99c.pdf.

Rhodes, R.A.W. (1997) Understanding Governance: policy networks, governance, reflexivity and accountability. Buckingham: Open University Press.

Ron, A. (2008) Power: A pragmatist, deliberative (and Radical) View. The Journal of Political Philosophy Vol. 16 No. 3 pp 272-292.

Rork, J.C. (2005). Getting what you pay for: The case of Southern economic development. Journal of Regional Analysis and Policy 35(2): 37-53.

Sanders, E. (1999) Roots of Reform. University of Chicago Press, Chicago.

Scott, M. (2002) 'Delivering Integrated Rural Development: Insights from Northern Ireland, European Planning Studies'. European Planning Studies Vol. 10 No.8, pp.1013-1025.

Scott, J. (2001) Power. Cambridge: Polity Press. 
Scott, M. (2004) Building institutional capacity in rural Northern Ireland: the role of partnership governance in the LEADER II programme. Journal of Rural Studies Vol.20 No.1 pp.49-59.

Shortall, S. and Shucksmith, M. (2001) Rural development in practice: issues arising in Scotland and Northern Ireland. Community Development Journal 36: 122-133.

Shortall, S. (2004) Social or economic goals, civic inclusion or exclusion? An analysis of rural development theory and practice. Sociologia Ruralis Vol. 44 No. 1 pp. 110-124

Shortall, S. (2005) Participation, community development and social exclusion. Paper presented to ESRC New Rural Economies Seminar Series 25/11/05.

Sivenas, N. (2006) The New Rural Development Regulation Leader Plus Magazine 6.

Stoker, G. (1998) Governance as theory: five propositions. International Social Science Journal No. 155 pp.17-28.

Skelcher, C., McCabe, A and Lowndes, V. (1996) Community networks in urban regeneration: 'It all depends who you know...!', Bristol: The Policy Press.

Storey, D. (1999) Issues of Integration, participation and empowerment in Rural Development: The case of LEADER in the Republic of Ireland. Journal of Rural Studies, vol. 15. No. 3 pp. 307-315.

Taylor, M. (2000) Communities in the Lead: Power, Organisational Capacity and Social Capital Urban Studies Vol. 37 No.5-6 pp. 1019-1035.

Taylor, M. (2007) Community participation in the real world: opportunities and pitfalls in new governance spaces. Urban studies Vol. 44 No.2 pp.297-317

Tendler, J. (1997) Good Government in the Tropics. Baltimore and London: Johns Hopkins University Press.

Tönnies, F. (1955) Community and association (Gemeinschaft und Gesellschaft) London: Routledge \& K. Paul.

United States Census Bureau, Population Division. American FactFinder. Accessed 1/05/10 at http://factfinder.census.gov/

United States Department of Agriculture, 2009. Rural Development Programs Summary. Accessed 2/22/10 at http://www.rurdev.usda.gov/al/ProgSummaryGuide.pdf.

Warner, M. and Shortall, S. (2008) Growth coalitions and rural development policy in the EU and the US. EuroChoices Point de Vue 7(3): 34-37. 
Warner, M. (2001) State policy under devolution: Redistribution and centralization. National Tax Journal Vol LIV(3): 541-556.

Warner, M. (2007) Market-Based Governance and the Challenge for Rural Governments: U.S. Trends. Social Policy and Administration: An International Journal of Policy and Research

Whitener, L. and Parker, T. (2007) Policy options for a changing rural America. Amber Waves, US Economic Research Service, May 2007.

Williams, J.J. (2004) Citizenship, Community Participation and Social Change: The Case of Area Coordinating Teams in Cape Town, South Africa. IDS Bulletin, Vol. 35 No.2, pp.19-25.

World Bank (2004) Local development discussion paper. Prepared for the International Conference on Local Development, Washington, DC: World Bank, 16-18 June. Available at http://www1.worldbank.org/sp/ldconference/Materials/LDDPFinal.pdf, last accessed 